A hypothesis is being examined in which an analogy is drawn between the two shear planes and the isotropic sections of strain ellipsoids produced by rotational stresses. When this is expanded to global application with the assumption of harmonic vibration in a rigid crust and a spiral rotational strainpattern, as expressed by the eccentricity of the geomagnetic axis, an interference pattern can be developed which not only shows conformity with some major global tectonics, but also suggests arcuate 'swirls' at each end of a Borneo-Caribbean axis, and rift shears at the ends of a conjugate Central PacificSouth African axis. Transparent spherical models are being used to study these coincidences, but no global conclusions are yet drawn. A full presentation of the application of interference fold principles to South Australian stratigraphy awaits the completion of precise photography of three-dimensional models.

\title{
OBITUARIES
}

\section{Dr. J. Kenyon, F.R.S.}

WiтH the death of Dr. Josoph Kenyon on November 12, chemistry lost one of its most beloved personalities, who was respected and esteemed throughout the world. To all those who had the honour of his personal acquaintance he was a very dear friend.

The son of Lawrence Kenyon, he was born at Blackburn on April 8, 1885, and, after obtaining on honours degree of the University of London, he became, in 1907, a lecturer at Blackburn Technical College and began research work with Dr. R. H. (later Sir Robert) Pickard. Although his first scientific publication, "Compounds of Tertiary Phosphine Oxides with Acids and Salts", appeared in 1906, the direction in which his future interests were to be concentrated was first signposted by his papers on "The Resolution of Racemic Alcohols" and "The Dependence of Rotatory Power on Chemical Constitution", published in 1909 and 1911.

The First World War caused a much greater disturbance of academic pursuits than did the Second, so it is not surprising to find that during this period Dr. Kenyon was engaged in research work on then vital problems. During 1915 and 1916, at the University of Loeds, he was exploring methods for the production of chloramine- $T$, and during 1916-20, at the University of Oxford, he was associated with the British Dyestuffs Corporation group. These investigations brought him into contact and personal friendship with J. B. Cohen and W. H. Perkin, jun., associations which he cherished very dearly later in life.

In 1920 Dr. Kenyon was appointed head of the Chemistry Department at Battersea Polytechnic, and under his great inspiration and wise guidance it developed into one of the foremost schools of chemistry in Britain, both for undergraduate education and postgraduate studies. This was achieved in spite of the fact that the funds and facilities then available for both teaching and research work were extremely limited.

On arriving at Battersea he took up again his interest in optical rotation as a tool in the study of chemical problems. In this work he was ably assisted over a number of years by H. Phillips, F. Bell, M. P. Balfe, C. L. Arcus, and many others now well known in various fields of chemistry. His name will always be perpetuated through his share in the establishment of the co-axial structure of diphenyl, for his investigations of the configurational changes occurring during the Walden inversion, and for his elucidation of the conditions under which the hydrolysis of an ester may be expected to take placo through acyloxygen fission or through alkyl-oxygen fission. As is evidenced by his large range of publications, principally in the Journal of the Chemical Society, however, these were only three of the many fields in which his investigations led to results of lasting importance, and he was remarkable for a clear insight into a wido range of chemical problems.

A quiet, modest man, Dr. Kenyon believed firmly that a good director of research work must himself enjoy working at the bench. He had the flair and intuition of the first-class experimenter, and his working technique was an example and inspiration to all his co-workers. He spurned the use of elaborate gadgets, his simple polarimeter and refractometer, with ordinary laboratory glassware, serving all his needs.

The Second World War saw Dr. Kenyon acting as senior gas adviser for the London area, and his discretion and confidence did much to unify a section of Civil Defence which, fortunately, was never called into active service.

In 1950 Dr. Kenyon retired from his post at Battersea Polytechnic, but he by no means retired from chemistry. Rather than take a well-earned rest he spent the winters of $1950-51$ and $1951-52$ as a visiting professor at the University of Alexandria, while during the session $1954-55$ he acted as professor in the University of Kansas. In the intervals, and until very shortly before his death, he continued to supervise the work of research students at Battersea, maintaining an undiminished zest for his subject to the end.

With his kindly persuasive manner, Dr. Kenyon did much to foster the interests of chemistry and of education in the wider fields outside of Battersea Polytechnic. He was an extremely valuable member of the Board of Studies in Chemistry of the University of London, and also served actively on the Boards of Examiners for both internal and external degrees. For a period he was a member of the Senate of the University.

Throughout his scientific career he was a Follow of the Chemical Society, and he served for various periods as a member of its Council and as one of its vice-presidents. $\mathrm{He}$ became an Associate of the Royal Institute of Chemistry in 1908 and a Follow in 1911, and he acted as an examiner for that body during 1937-44. Acting on its behalf, ho also did a great deal in assisting the National Certificate scheme by acting as assessor in organic chemistry for both the Ordinary and Higher National Certificates. His wisdom, together with his wide knowledge of his subject, caused him to be called on frequently, not only by the University of London but also by other universities, to act as an examiner for both first and higher degrees. Ho was elected a Fellow of the Royal Society in 1936.

A scholar in the widest sense of the term, Dr. Kenyon had a keen appreciation of the arts and a 
profound knowledge of the classics. His garden, which furnished the rosebuds or sprigs of honeysuckle which he was wont to sport in his buttonhole, gave him much joy. For many years, too, he looked forward to his weekly round of golf. Happily he enjoyed good health until late in 1960, when, much to his regret, illness prevented his attendance at a gathering of former members of his Department, who had come from all over the country to do him honour.

Dr. Kenyon was married in 1917, and he is survived by his wife and only daughter. By his former undergraduate students he will be remembered as a careful and lucid lecturer, with a clear understanding of the problems which beset a student, but intolerant of slackness and slovenliness. His research students will recall his kindly and inspiring supervision of their work. Those who had the pleasure of serving on his staff will appreciate the encouragement he gave them in their research work, irrespective of the topics in which they were interested, and the manner in which he consulted them on all vital matters. All who knew him mourn the loss of a great chemist, of a great scholar, and, above all, of a great gentleman.

$$
\text { J. W. Sмгтн }
$$

\section{Prof. F. G. Gregory, F.R.S.}

WITH the death on November 27 of F. G. Gregory, plant science has lost one of its most dynamic twentieth-century personalities. Gregory was born on December 22, 1893, and attended the Dame Alice Owen School. From the time he left school until his retirement in 1958 - a period of forty-six years-he was associated with the Imperial College of Science and Technology (University of London). After graduating with first-class honours in botany, he joined the staff of the Research Institute of Plant Physiology, which was directed by Prof. V. H. Blackman. Later, he became assistant director of the Institute and eventually succeeded Blackman both as director and as professor of plant physiology in the Imperial College. He was elected a Fellow of the Royal Society in 1940, and a foreign member of the U.S. National Academy of Sciences in 1956. In 1957 he was awarded a Royal Medal of the Royal Society.

This, the bare outline of a highly successful academic career, gives little idea of the lifetime of high adventures of the mind which characterized it. Gregory had an unusual equipment in chemistry, physics and mathematics and as well an insatiable scientific curiosity. He brought his great breadth of knowledge to bear on a wide range of topics and illuminated them all. He began his researches at the time that the potential contribution of plant physiology to agriculture had been recognized by the establishment of the Research Institute under the auspices of the Ministry of Agriculture. Soon there began to appear in the Annals of Botany the series of papers which form a corner stone in the foundations of modern quantitative physiology. His name is especially linked with studies of methods of growth analysis, mineral nutrition and vernalization of cereals, and with important advisory work on cotton-growing in the Sudan. When the Agricultural Research Council took over responsibility for the Institute, Gregory served on many of its committees, but his primary interest remained always the daily events of the laboratory with which he never lost contact.
His published work records only part of his contribution to science; he will be remembered as much for his unique capacity to fire others with his own passion for inquiry. No one worked under Gregory, they worked with him; he was at their service to consider every notion with acumen and enthusiasm and to elicit from each one better than his best. His complex character with its often exaggerated response to events was capable as well of providing continuous encouragement and sympathy, and those who experienced his many kindnesses know how much time and trouble were spent in the consideration of their welfare. It was a source of deep satisfaction to him at the dinner given in his honour on retirement to see assembled so many of his former students and colleagues now themselves directing research.

His relaxations, pursued with equal fervour, were music (he was both a composer and an accomplished pianist) and philosophy. He was a voracious reader and had a considerable collection of books which he bequeathed to the Imperial College. He was un married.

Helen K. Porter

\section{Prof. C. H. O'Donoghue}

VIVID memories of zoology classes will have been recalled to many former students by the news of the death on November 28 of C. H. O'Donoghue, professor emeritus in the University of Reading, at the age of seventy-six. As a teacher he had the gift of presenting his material in a way made memorable by humour and of matching his subject with illuminating wit. To the many students who passed through his classes. either on the way to more advanced zoological studies or to medical or other scientific work, these are one of the more enduring memories of their undergraduate days. Though he often masked his serious purpose with a deliberately informal manner, O'Donoghue expected a high standard of work from his students and taught them to appreciate the impor. tance of the great general principles of zoology. These were usually in relation to comparative anatomy, which he clearly regarded as the most important ingredient of zoology as an educational subject. This does not mean, however, that he was not interested in other branches of the science, for he had a far-reaching knowledge of both marine and freshwater zoology, and an extraordinarily wide knowledge of animals of all sorts. He learned his zoology before the modern application of physics and chemistry to the study of animals and, though he appreciated the findings of this newer work, was never really at home in it.

As a research worker O'Donoghue made his reputa. tion first as an anatomist, and the series of papers on the vascular system of Sphenodon, Tropidonotus and Squalus are standard accounts. To this series also belongs the paper on abnormalities in the anuran vascular system which earned him the Neil Medal of the Royal Society of Edinburgh in 1932. In addition to this anatomical work on vertebrates, O'Donoghue also carried out taxonomic work on nudibranch molluses and bryozoans and is perhaps better known to more people as a specialist in one or other of these groups. It was mainly in Bryozoa that he had latterly interested himself, and he was still at work on collections of these animals up to the time of his death.

Charles Henry O'Donoghue was born in Bedford. shire in 1885 . He went to King's College, London, as 